\title{
NILAI ANAK DAN PERSEPSI TERHADAP PENDIDIKAN ANAK SERTA HUBUNGANNYA DENGAN TINGKAT PENDIDIKAN ANAK PETANI (Studi Kasus di Kelompok Tani Giri Senang Kabupaten Bandung)
}

\section{CHILDREN'S VALUES AND PERCEPTIONS OF CHILDREN'S EDUCATION AND THEIR RELATIONSHIP WITH THE EDUCATIONAL LEVEL OF FARMER'S CHILDREN (Case Study in the Giri Glad Farmers Group, Bandung Regency)}

\author{
Devia Destriyani*, Rani Andriani Budi Kusumo
}

Program Studi Agribisnis, Fukultas Pertanian, Universitas Padjadjaran

Jl. Raya Bandung Sumedang KM. 21, Hegarmanah, Jatinangor, Kabupaten Sumedang 45363

*Email: Deviadestriyani12@gmail.com

(Diterima 18-02-2021; Disetujui 03-06-2021)

\begin{abstract}
ABSTRAK
Kelompok Tani Giri Senang memiliki anggota yang rata-rata tidak menyelesaikan pendidikan 12 tahun. Tujuan dari penelitian ini adalah mengetahui nilai anak bagi keluarga, persepsi keluarga tentang pendidikan anak, tingkat pendidikan anak, dan hubungan nilai anak dan persepsi keluarga tentang pendidikan anak dengan tingkat pendidikan anak di Kelompok Tani Giri Senang. Penelitian ini menggunakan pendekatan kuantitatif dengan metode survei dan analisis menggunakan analisis deskriptif. Penentuan responden menggunakan teknik random sampling yang berjumlah 34 respoden. Hasil penelitian menunjukkan sebagian besar petani menilai bahwa anak lebih memiliki nilai psikologis dibandingkan nilai sosial dan ekonomis. Orang tua menganggap anak sebagai berkah dan keberadaannya membuat keluarga menjadi lengkap. Persepsi keluarga petani tentang pendidikan anak menunjukkan bahwa pendidikan sangat penting bagi anak, namun tingkat pendidikan anak keluarga petani di Kelompok Tani Giri Senang dominan hanya sampai SD dengan persentase $45,83 \%$ dan terendah berada pada tingkat perguruan tinggi dengan persentase $1,04 \%$. Dalam hubungan nilai anak dan persepsi keluarga tentang pendidikan anak dengan tingkat pendidikan anak keluarga petani Kelompok Tani Giri Senang memiliki korelasi yang sangat lemah dan tidak signifikan. Oleh karena itu, diharapkan orang tua secara aktif memotivasi dan memberikan wawasan kepada anak pentingnya pendidikan bagi kehidupan.
\end{abstract}

Kata Kunci : Nilai Anak, Persepsi Pendidikan, Petani

\section{ABSTRACT}

The Giri Senang Farmer Group has members who on average have not completed 12 years of education. The purpose of this study is to determine the value of children for families, family perceptions of children's education, chindren's education level, and the correlation between children's values and family perceptions of children's education with the level of children's education in the Giri Senang Farmer Group. This research uses a quantitative approach with survey methods and analysis using descriptive analysis. Determination of respondents using random sampling techniques, amounting to 34 respondents. The results showed that most of the agricultural laborers considered that children had more psychological values than social and economic values. Parents consider their children a blessing and their existence makes the family complete. Farm worker families' perceptions about children's education show that education is very important for children, but the educational level of farmworker family children in the Giri Senang Farmers Group is dominant only up to elementary school with a percentage of $45,83 \%$ and the lowest is at the college level with a percentage of 1,04\%. In the correlation between children's values and family perceptions about children's education with the level of education of the family children of farm workers the Giri Senang Farmer Group has a very weak and insignificant 
correlation. Therefore, it is hoped that parents can actively motivate and provide insight into the importance of education for life.

Keywords : Value of Children, Perception of Education, Farmer's

\section{PENDAHULUAN}

Indonesia dikenal sebagai negara agraris, karena sebagian penduduknya berprofesi sebagai petani. Petani adalah pemasok utama sebagian besar kebutuhan pangan masyarakat di Indonesia dan memegang peranan penting. Oleh karena itu, petani seharusnya mempunyai nilai tawar yang tinggi dan kesejahteraan mereka diperhatikan oleh pemerintah. Para petani memiliki keluarga yang harus mereka jaga dan hidupi seperti para pekerja non pertanian. Mereka harus memenuhi semua kebutuhan rumah tangganya dengan hasil dari sektor pertanian yang mereka geluti.

Kesejahteraan erat hubungannya dengan penduduk tidak miskin dan penduduk miskin. Badan Pusat Statistik (BPS) menyatakan bahwa penduduk miskin adalah penduduk yang memiliki rata-rata pengeluaran per kapita per bulan di bawah garis kemiskinan. Jumlah masyarakat di bawah garis kemiskinan akan mempengaruhi tingkat kemiskinan suatu daerah. Menurut BPS Provinsi Jawa Barat, tingkat kemiskinan Jawa Barat mengalami kenaikan dari tahun sebelumnya.

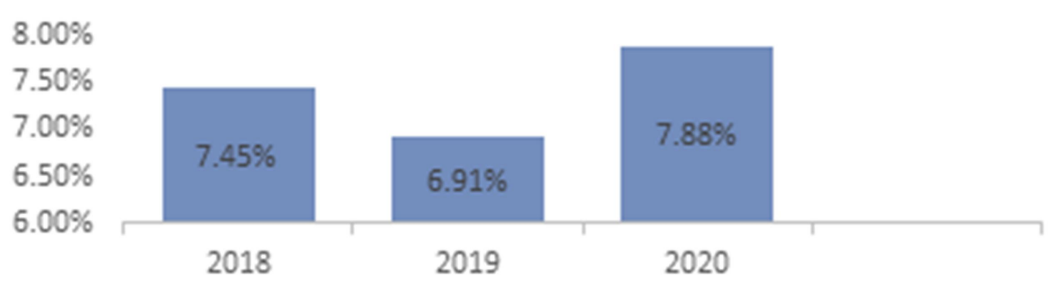

Gambar 1. Jumlah Presentase Penduduk Miskin di Jawa Barat

Salah satu faktor yang dapat mempengaruhi tingkat kesejahteraan keluarga adalah pendidikan. Tidak dapat dipungkiri bahwa pendidikan merupakan komponen yang penting. Pembangunan manusia melalui pendidikan ialah pembangunan manusia yang memiliki tingkat kompetisi tinggi, daya saing, dan memiliki wawasan yang luas (Pradata, 2013). Ki Hajar Dewantara mengatakan, "Kemajuan sebuah bangsa terletak pada 
pendidikan dan para generasi bangsa itu sendiri".

Siregar (2013) menyatakan bahwa pendidikan merupakan hal essensial bagi manusia karena dengan pendidikan manusia dapat belajar mengahadapi berbagai problematika untuk mempertahankan kehidupannya. Sasaran pembangunan di bidang pendidikan nasional adalah dengan meningkatkan mutu pendidikan yang merupakan bagian intergral dari upaya peningkatan kualitas manusia Indonesia secara menyeluruh. Dalam hal ini, kebutuhan pendidikan adalah suatu hal yang penting dan memerlukan pertimbangan yang cukup matang bagi setiap keluarga.

Rendahnya tingkat pendidikan anak dapat dipengaruhi pendapatan ekonomi orang tua (Rosyid, 2016). BPS menyatakan sebanyak 49,41\% Rumah Tangga (RT) miskin bekerja di sektor pertanian. Banyaknya petani yang mengalami kemiskinan berakibat tidak meratanya pendidikan bagi anak karena kesulitan dalam hal ekonomi. Di Indonesia terdapat banyak anak putus sekolah yang diantaranya terdapat pula anak dari petani.

Tabel 1. Data Jumlah Siswa Putus Sekolah Terbesar Tiap Provinsi Tahun 2019/2020

\begin{tabular}{clrrrr}
\hline \multirow{2}{*}{ No. } & \multicolumn{1}{c}{ Provinsi } & \multicolumn{3}{c}{ Tingkat } & \multirow{2}{*}{ Jumlah (orang) } \\
\cline { 3 - 4 } & & SD & SMP & SMA & 11.593 \\
\hline 1. & Prov. Jawa Timur & 4.919 & 4.477 & 2.197 & 11.295 \\
2. & Prov. Jawa Barat & 6.030 & 3.684 & 1.581 & 9.835 \\
3. & Prov. Sumatera Utara & 4.106 & 3.403 & 2.326 & 7.999 \\
4. & Prov. Sulawesi Selatan & 3.092 & 2.312 & 2.955 & 7.760 \\
5. & Prov. Nusa Tenggara Timur & 3.344 & 2.406 & 2.010 & \\
\hline
\end{tabular}

Sumber: Kementerian Pendidikan dan Kebudayaan Sekretarian Jenderal Pusat Data dan Statistik Pendidikan dan Kebudayaan 2020

Tabel 1 di atas menunjukkan bahwa Provinsi Jawa Barat memiliki jumlah anak putus sekolah kedua terbanyak dengan total 11.295 orang pada tahun 2019/2020. Gubernur Jawa Barat Bapak Ridwan Kamil pada tahun 2019 menyuarakan \#JabarJuara yang maju dan merata bersama dengan program peningkatan indeks sarjana Jabar. Oleh karena itu, program tersebut akan berjalan jika anak putus sekolah juga berkurang. Pemerintah Indonesia sejak tahun 2013 merintis program pendidikan menengah universal atau pendidikan 12 tahun yang diharapkan tuntas pada tahun 2025 secara gratis. 
NILAI ANAK DAN PERSEPSI TERHADAP PENDIDIKAN ANAK

SERTA HUBUNGANNYA DENGAN TINGKAT PENDIDIKAN ANAK PETANI

Devia Destriyani, Rani Andriani Budi Kusumo

Tabel 2. Angka Partisipasi Sekolah per Kota/Kabupaten di Jawa Barat Tahun 2017-2019

\begin{tabular}{lcrrrrr}
\hline \multirow{2}{*}{ Tahun } & Jenjang & Kota Bekasi & $\begin{array}{c}\text { Kota } \\
\text { Bandung }\end{array}$ & $\begin{array}{c}\text { Kabupaten } \\
\text { Majalengka }\end{array}$ & $\begin{array}{c}\text { Kabupaten } \\
\text { Kuningan }\end{array}$ & $\begin{array}{c}\text { Kabupaten } \\
\text { Bandung }\end{array}$ \\
\cline { 2 - 7 } 2017 & $7-12$ & 99,83 & 99,82 & 99,36 & 100 & 99,87 \\
\cline { 2 - 7 } & $13-15$ & 96,20 & 95,55 & 95,78 & 80,89 & 90,72 \\
\hline 2018 & $16-18$ & 78,36 & 75,68 & 68,78 & 74,88 & 62,16 \\
\cline { 2 - 7 } & $7-12$ & 100 & 99,89 & 99,85 & 99,25 & 99,83 \\
\hline 2019 & $13-15$ & 97,52 & 96,81 & 96,18 & 88,67 & 91,18 \\
\cline { 2 - 7 } & $16-18$ & 84,33 & 78,04 & 73,85 & 76,50 & 65,57 \\
\cline { 2 - 7 } & $7-12$ & 99,77 & 99,80 & 99,71 & 99,86 & 99,69 \\
\hline & $13-15$ & 97,91 & 96,47 & 96,35 & 89,29 & 90,48 \\
\hline
\end{tabular}

Sumber: Badan Pusat Statistik Jawa Barat, 2020

Tabel 2 di atas menunjukkan bahwa Kabupaten Bandung memiliki angka partisipasi sekolah yang lebih kecil dibandingkan dengan kota/kabupaten lain di Jawa Barat. Angka partisipasi sekolah di Kabupaten Bandung cenderung menurun tiap tahunnya. Hal tersebut menandakan bahwa semakin berkurang siswa usia sekolah yang bersekolah di Kabupaten Bandung.

Tingkat pendidikan anak di setiap keluarga dapat berbeda-beda. Salah satu faktor yang dapat mempengaruhi tingkat pendidikan anak adalah pandangan keluarga tersebut mengenai nilai anak (Hastuti, 2011). Kasnodihardjo (2014) menyatakan bahwa sejatinya keberadaan anak dalam keluarga memiliki nilai bagi orang tua. Keberadaan anak memiliki nilai tertentu di mata keluarga seperti nilai ekonomi, sosial dan budaya. Nilai anak di dalam keluarga dapat dilihat dari sisi ekonomi dan non ekonomi tergantung bagaimana orang tua melihatnya.
Hoffman et al (1978) menyebutkan bahwa terdapat sembilan dimensi nilai anak. Dalam penelitian Hartoyo et al (2011) menyebutkan bahwa banyak orang tua yang menilai anak secara berbeda. Anak akan mendapatkan perlakuan khusus bagi anak yang memiliki nilai tinggi di mata orang tua. Nilai anak akan mempengaruhi pengalokasian sumberdaya yang dilakukan orang tua. Adanya perbedaan terhadap nilai anak di dalam keluarga dapat mempengaruhi pola pengasuhan yang akan berhubungan dengan kualitas anak dan tingkat pendidikan anak. Perbedaan dalam menilai anak juga dapat terjadi pada keluarga petani. Mereka dapat menilai anaknya secara berbeda karena anak adalah harapan bagi keluarganya, baik itu dalam hal ekonomi, sosial, dan budaya, dan itu semua tujuannya untuk meningkatkan kesejahteraan.

Kecamatan Cilengkrang merupakan salah satu kecamatan yang berada di 
Kabupaten Bandung. Berdasarkan Badan Pusat Statisik Kabupaten Bandung (2020) bahwa Kecamatan Cilengkrang memiliki jumlah siswa bersekolah paling sedikit dibandingkan dengan kecamatan lain di Kabupaten Bandung. Terdapat 6 desa di Kecamatan Cilengkrang, salah satunya adalah desa Giri Mekar yang memiliki jumlah keluarga petani paling banyak sebanyak 635 keluarga dari 2.007 keluarga pertanian.

Desa Giri Mekar memiliki 3.836 kepala keluarga. Diantaranya terdapat 1.079 keluarga kurang mampu dan 296 keluarga tidak mampu. Jumlah penduduk Desa Giri Mekar usia sekolah ke atas berjumlah 12.101 orang dan yang menyelesaikan pendidikan hanya 2.816 orang.

Tabel 3. Penduduk Desa Giri Mekar yang Menyelesaikan Pendidikan

\begin{tabular}{lr}
\hline \multicolumn{1}{c}{ Jenjang Pendidikan } & Jumlah (orang) \\
\hline SD & 1.261 \\
SMP & 853 \\
SMA & 468 \\
Perguruan Tinggi & 119 \\
Kejar Paket A dan lain-lain & 115 \\
\hline Jumlah & 2.816 \\
\hline Sumber: Data Statistik Desa Giri Mekar 2019
\end{tabular}

Penduduk Desa Giri Mekar yang bekerja berjumlah 6.767 orang dan sebanyak 2.255 orang bekerja di sektor pertanian. Kelompok Tani Giri Senang adalah salah satu kelompok tani di Desa Giri Mekar yang berkecimpung di komoditas Kopi Palasari yang bertempat di Legok Nyenang Rt 01 Rw 01 Kec. Cilengkrang Kabupaten Bandung, Jawa Barat. Kelompok Tani Giri Senang berhasil menyandang status sebagai wanawiyata widyakarya (Lembaga Pelatihan dan Pemagangan Usaha Kehutanan Swadaya) sejak tahun 2016. Kelompok Tani Giri Senang menjadi salah satu lokasi di Kabupaten Bandung yang sedang dikembangkan menjadi Kampung Kopi. Kampung ini merupakan salah satu dari sekian banyak kampung edukasi di Kabupaten Bandung yang mendapatkan penghargaan dari Dinas Lingkungan Hidup di bidang edukasi lingkungan. Kopi hasil produksi Kelompok Tani Giri Senang dengan brand Kopi Palasari berhasil memenuhi permintaan beberapa cafe dari Bandung dan daerah lainnya, seperti Yogyakarta, Jakarta dan Bali. Karena memiliki kopi arabika dengan kualitas unggulan, kopi palasari berhasil menjajaki pasar Eropa.

Kelompok Tani Giri Senang beranggotakan 108 orang. Dari data yang didapatkan dari hasil wawancara dengan anggota Kelompok Tani Giri Senang, hampir $90 \%$ anggota tersebut tidak menyelesaikan pendidikan wajib belajar 12 tahun. Sebelumnya dari angka partisipasi sekolah bahwa Kabupaten Bandung cenderung rendah yang berarti 
siswa usia sekolah yang bersekolah cukup rendah. Anggota Kelompok Tani Giri Senang sebagian besar telah berkeluarga dan memiliki anak. Sebagian besar dari mereka merupakan pekerja petani yang menggarap hasil lahan milik orang lain dan di upah per harinya. Desa Giri Mekar ini merupakan tempat yang hasil perkebunannya berupa kopi yang memiliki potensi tinggi untuk berkembang. Dengan berkembangnya perkebunan kopi ini, maka diharapkan akan meningkatkan kesejahteraan keluarga petani tersebut.

Berdasarkan data banyaknya jumlah petani di Kelompok Tani Giri Senang yang tidak melanjutkan pendidikan, diperlukan kajian mengenai pandangan anggota tentang pendidikan dan keberlanjutan pendidikan anaknya dengan mengetahui bagaimana nilai anak yang mencakup nilai anak sosial, nilai anak ekonomi, nilai anak psikologis bagi keluarga petani, bagaimana persepsi keluarga petani terhadap pendidikan anak, dan bagaimana tingkat pendidikan anak keluarga petani.

\section{METOE PENELITIAN}

Desain yang digunakan dalam penelitian ini adalah metode kuantitatif dengan teknik survei. Penelitian ini dilakukan di Kelompok Tani Giri Senang Desa Giri Mekar, Kecamatan Cilengkrang, Kabupaten Bandung, Jawa Barat. Alasan penelitian dilakukan di Kelompok Tani Giri Senang adalah banyaknya anggota kelompok tani ini yang telah berkeluarga dan memiliki keturunan, namun mereka tidak menyelesaikan pendidikan wajib belajar 12 tahun.

Populasi pada penelitian ini adalah anggota Kelompok Tani Giri Senang di Desa Giri Mekar, Kecamatan Cilengkrang, Kabupaten Bandung, Jawa Barat yang sesuai dengan karakteristik responden pada penelitian ini, yaitu: (1) Keluarga petani di kelompok Tani Giri Senang, (2) Masih aktif berkerja di lahan, (3) Memiliki keluarga (suami, istri, anak), (4) Anak berusia minimal 12 tahun. Dari karakteristik tersebut didapat jumlah populasi sebanyak 51 anggota. Penentuan jumlah sample menggunakan teknik Slovin dengan tingkat toleransi kesalahan $10 \%$, dan diperoleh ukuran sampel sebanyak 34 orang anggota Kelompok Tani Giri Senang yang diambil sebagai responden. Teknik pengambilan sampel digunakan teknik random sampling.

Variabel dalam penelitian ini sebagai berikut: 1) Nilai Anak, menurut Hoffman, Thornton, dan Manis (1978) 
nilai anak adalah kepuasan psikologis orang tua atas jasa yang diberikan anak (child service). Nilai anak memiliki 3 dimensi menurut Kagitcibasi, yaitu: a) Nilai Anak Psikologis: orang tua menilai anak sebagai sebuah anugerah yang diberikan oleh Tuhan. Anak menjadi tempat orang tua untuk mencurahkan kasih sayang. b) Nilai Anak Ekonomis: anak dilahirkan dan dibesarkan tidak lain dan tidak bukan yaitu untuk membantu orang tua. Bantuan dari anak tersebut dapat berupa tenaga kerja maupun materi.

c) Nilai Anak Sosial: anak diperlukan keberadaanya untuk melanjutkan nama atau tradisi keluarga. Anak juga dipandang untuk meningkatkan status sosial mereka di masyarakat. 2) Persepsi Pendidikan, Siregar (2013) menyatakan persepsi adalah pengamatan (penyusunan dorongan-dorongan dalam kesatuan kesatuan) hal mengetahui, melalui indera (tanggapan atau daya memahami). Persepsi orang tua tentang pendidikan adalah cara pandang atau pemahaman orang tua tentang pendidikan. Persepsi Orang tua tersebut meliputi pemahaman orang tua mengenai pendidikan, tanggapan orang tua mengenai pendidikan dan gambaran orang tua tentang pendidikan. 3) Tingkat Pendidikan, Pratiwi (2015) menyebutkan tingkat pendidikan adalah tahapan pendidikan yang ditetapkan berdasarkan tingkat perkembangan peserta didik, tujuan yang akan dicapai dan kemauan yang dikembangkan. Tingkat pendidikan yang lebih tinggi akan memudahkan sesorang atau masyarakat untuk menyerap informasi dan mengimplementasikannya dalam perilaku dan gaya hidup sehari-hari.

Pada penelitian ini teknik pengumpulan data yang digunakan adalah wawancara, observasi, studi literatur, dan kuesioner. Instrumen yang digunakan pada penelitian ini menggunakan skala likert. Analisis data dibantu dengan menggunakan program SPSS. Data yang diperoleh dianalisis menggunakan teknik analisis deskriptif.

\section{HASIL DAN PEMBAHASAN}

\section{Nilai Anak Psikologis}

Anak bernilai psikologis yaitu orang tua menilai anak sebagai sebuah anugerah yang diberikan oleh Tuhan. Hasil penelitian tentang nilai anak psikologis, ditunjukkanan pada Tabel 4.

Tabel 4. Sebaran berdasarkan Dimensi Nilai Anak Psikologis

\begin{tabular}{lcc}
\multicolumn{1}{c}{ Kategori } & Frekuensi & $\%$ \\
\hline Rendah & 0 & $0 \%$ \\
\hline Sedang & 4 & $12 \%$ \\
\hline Tinggi & 30 & $88 \%$ \\
\hline Total & 34 & $100 \%$ \\
\hline Total Skor & \multicolumn{2}{c}{1.393} \\
\hline Mean & \multicolumn{2}{c}{4,097} \\
\hline
\end{tabular}


Tabel 4 menunjukkan bahwa persepsi orang tua mengenai anak memiliki nilai psikologis dengan skor 1.393 tergolong dalam kategori tinggi. Hal ini mengartikan orang tua Kelompok Tani Giri Senang setuju bahwa anak merupakan anugerah dari Tuhan, dan anak memiliki fungsi psikologis bagi orang tua. responden pada penelitian ini didominasi memilih setuju terhadap nilai anak psikologis karena percaya bahwa anak merupakan anugerah dari Tuhan untuk mecurahkan kasih sayang karena anak merupakan sebuah berkah dan keberadaan anak membuat keluarga menjadi lengkap, responden menganggap anak memberikan kebahagiaan bagi mereka dan membuat mereka semangat untuk bekerja. Hasil ini setara dengan penelitian oleh Hastuti (2011) yang menyatakan bahwa orang tua menganggap anak sebagai kebahagiaan, dan mempererat hubungan suami istri. Pada penelitian Mardiana (2014) orang tua secara umum menyetujui bahwa kehadiran anak dapat memberikan manfaat secara psikologis.

\section{Nilai Anak Ekonomis}

Anak bernilai ekonomi yaitu anak dilahirkan dan dibesarkan tidak lain dan tidak bukan yaitu untuk membantu orang tua. Hasil penelitian tentang nilai anak ekonomis, ditunjukkan pada Tabel 5.

Tabel 5. Sebaran berdasarkan Dimensi Nilai Anak Ekonomis

\begin{tabular}{lcc}
\hline \multicolumn{1}{c}{ Kategori } & Frekuensi & $\%$ \\
\hline Rendah & 3 & $9 \%$ \\
\hline Sedang & 23 & $68 \%$ \\
\hline Tinggi & 8 & $23 \%$ \\
\hline Total & 34 & $100 \%$ \\
\hline Total Skor & \multicolumn{2}{c}{614} \\
\hline Mean & \multicolumn{2}{c}{3,325} \\
\hline
\end{tabular}

Tabel 5 menunjukkan bahwa persepsi orang tua mengenai anak memiliki nilai ekonomis dengan skor 614 tergolong dalam kategori sedang. Hal ini mengartikan bahwa orang tua di Kelompok Tani Giri Senang tidak sepenuhnya menganggap anak sebagai fungsi ekonomi dan anak bukan merupakan beban dalam keluarga. Sebagian responden setuju bahwa anak harus membalas budi orang tua, dan mengharapkan anak dapat membantu perekonomian keluarga, dan setuju untuk biaya memberi makan, pakaian, dan biaya sekolah anak cukup besar namun sebagian responden juga menganggap anak bukan sebagai fungsi ekonomi dan anak bukan sebuah beban dalam keluarga melainkan sebuah tanggung jawab orang tua.

Responden kurang menganggap anak sebagai investasi masa depan orang tua karena meskipun orang tua mengharapkan anak dapat membantu 
perekonomian keluarga, hal itu jika anak tersebut memiliki keadaan ekonomi yang cukup dan anak tersebut dapat menghidupi dirinya sendiri dan keluarganya, serta atas kesadaran sendiri dalam membantu orang tua. Dalam penelitian Bahri et al (2013) menyatakan perbedaan kondisi sosial ekonomi berdampak pada berbedaan nilai anak dan perilaku investasi. Investasi orang tua pada anak adalah upaya untuk menghasilkan sumperdaya yang berkualitas melalui alokasi uang dan waktu. Anak diharapkan dapat memberikan manfaat ekonomi dan jaminan di hari tua.

\section{Nilai Anak Sosial}

Anak bernilai sosial yaitu anak diperlukan untuk melanjutkan nama keluarga. Hasil penelitian tentang nilai anak ekonomis, ditunjukkan pada Tabel 6.

Tabel 6. Sebaran berdasarkan Dimensi Nilai Anak Sosial

\begin{tabular}{lcc}
\hline \multicolumn{1}{c}{ Kategori } & Frekuensi & $\%$ \\
\hline Rendah & 0 & $0 \%$ \\
\hline Sedang & 4 & $12 \%$ \\
\hline Tinggi & 30 & $88 \%$ \\
\hline Total & 34 & $100 \%$ \\
\hline Total Skor & \multicolumn{2}{c}{1.371} \\
\hline Mean & \multicolumn{2}{c}{4,032} \\
\hline
\end{tabular}

Tabel 6 menunjukkan bahwa persepsi orang tua mengenai anak memiliki nilai sosial memiliki skor 1.371 dan tergolong dalam kategori tinggi. Hal ini mengartikan orang tua Kelompok Tani Giri Senang setuju bahwa anak merupakan kebanggaan keturunan dan anak memiliki fungsi sosial. Responden pada penelitian ini setuju bahwa anak merupakan ahli waris dalam keluarga dan merupakan kebanggaan keturunan keluarga mereka, dan mereka merasa bangga di depan masyarakat jika memiliki anak yang cerdas. Responden menilai bahwa anak yang berperilaku baik akan menimbulkan rasa bangga di depan masyarakat, namun mereka tidak merasa malu di depan masyarakat jika anaknya memiliki perilaku yang buruk. Selaras dengan penelitian Fahmi et al (2018) yang menyatakan bahwa sebagian besar responden memilih anak sebagai nilai sosial dikarenakan responden setuju bahwa anak sumber ketentraman karena orang tua merasa lengkap di lingkungan sosial karena memiliki anak dan meningkatkan status sosial mereka di masyarakat.

\section{Persepsi Keluarga tentang Pendidikan Anak}

Persepsi orang tua tentang pendidikan adalah cara pandang atau pemahaman orang tua tentang pendidikan. Hasil penelitian tentang persepsi keluarga tentang pendidikan anak ditunjukkan pada Tabel 7. 
Tabel 7. Sebaran berdasarkan Dimensi Persepsi Keluarga tentang Pendidikan Anak

\begin{tabular}{lcc}
\hline \multicolumn{1}{c}{ Kategori } & Frekuensi & $\%$ \\
\hline Rendah & 0 & $0 \%$ \\
\hline Sedang & 0 & $0 \%$ \\
\hline Tinggi & 34 & $100 \%$ \\
\hline Total & 34 & $100 \%$ \\
\hline Total Skor & \multicolumn{2}{c}{2.418} \\
\hline Mean & \multicolumn{2}{c}{4,097} \\
\hline
\end{tabular}

Berdasarkan hasil penelitian yang terlihat pada Tabel 7 terungkap bahwa persepsi keluarga petani tentang pendidikan adalah sangat baik dengan total skor 2.418. Berdasarkan hasil wawancara di lapangan bahwa seluruh responden berjumlah 34 responden setuju bahwa pendidikan sangat penting bagi anak. Responden setuju bahwa pendidikan sangat penting bagi anak dan anak harus memiliki pengetahuan agama yang luas serta berharap anak akan menjadi anak yang cerdas, memiliki pengetahuan yang luas, mendapatkan pekerjaan yang lebih baik, dan hidup lebih sejahtera. Selaras dengan penelitian Solina (2017) yang menyatakan bahwa sebagian besar responden memiliki persepsi positif tenang pendidikan. Hal ini karena orang tua menganggap pendidikan penting bagi anak dan melaui pendidikan dapat meningkatkan segala aspek dalam kehidupan. Dalam hal ini orang tua memiliki peranan penting dalam mendidikan anak.

\section{Tingkat Pendidikan Anak}

Tingkat pendidikan adalah tahapan pendidikan yang ditetapkan berdasarkan tingkat perkembangan peserta didik, tujuan yang akan dicapai dan kemauan yang dikembangkan. Hasil penelitian tentang tingkat pendidikan anak keluarga petani, ditunjukkanan pada Tabel 8 .

Tabel 8. Tingkat Pendidikan Anak Keluarga Petani

\begin{tabular}{clcccccc}
\hline \multirow{2}{*}{ No } & Tingkat Pendidikan & \multicolumn{2}{c}{ Telah Lulus } & \multicolumn{2}{c}{ Belum Lulus } & \multicolumn{2}{c}{ Total } \\
\cline { 3 - 8 } & & $\mathrm{f}$ & $\%$ & $\mathrm{~F}$ & $\%$ & $\mathrm{f}$ & $\%$ \\
\hline 1. & Tidak/Belum Sekolah & 0 & 0 & 11 & 34,38 & 11 & 11,46 \\
\hline 2. & SD & 39 & 60,94 & 5 & 15,62 & 44 & 45,83 \\
\hline 3. & SMP & 9 & 14,06 & 7 & 21,88 & 16 & 16,67 \\
\hline 4. & SMA & 15 & 23,44 & 9 & 28,12 & 24 & 25 \\
\hline 5. & Perguruan Tinggi & 1 & 1,56 & 0 & 0 & 1 & 1,04 \\
\hline Total & 64 & 100 & 32 & 100 & 96 & 100 \\
\hline
\end{tabular}

Berdasarkan hasil penelitian yang terlihat pada Tabel 8 terungkap bahwa tingkat pendidikan anak keluarga petani yang telah menyelesaikan usia sekolahnya didominasi tingkat pendidikan Sekolah Dasar (SD). Anak keluarga petani yang masih dalam usia sekolah hanya sebanyak 21 anak dan 11 anak berada pada usia belum sekolah. Tingkat pendidikan anak anggota Kelompok Tani Giri Senang didominasi hanya sampai tingkat sekolah dasar 
dikarenakan permasalahan biaya yang cukup besar untuk menyekolahkan anak dan beberapa anak memilih untuk tidak melanjutkan pendidikan atas dasar keinginan mereka sendiri dan lebih memilih untuk langsung bekerja. Dengan adanya sekolah gratis dari pemerintah sangat membantu anak keluarga petani melanjutkan pendidikan. Namun, biaya yang dikeluarkan untuk anak sekolah masih cukup tinggi karena untuk membeli keperluan lainnya, serta tidak semua anak keluarga petani Kelompok Tani Giri Senang dapat bersekolah di sekolah negeri.

\section{Hubungan Nilai Anak dan Persepsi Keluarga Petani dengan Pendidikan Anak terhadap Tingkat Pendidikan Anak}

\subsection{Hubungan Nilai Anak Psikologis dengan Tingkat Pendidikan Anak}

Hasil perhitungan korelasi rank spearman dengan SPSS antara nilak anak psikologis dengan tingkat pendidikan anak ditunjukkan dalam Tabel 9.

Tabel 9. Korelasi Nilai Anak Psikologis dengan Tingkat Pendidikan Anak

\begin{tabular}{cccc}
\hline Karakteristik & Koefesien Korelasi & Signifikansi (2-tailed) & Keterangan \\
\hline Nilai Anak Psikologis & 0,19 & 0,282 & Tidak Signifikan \\
\hline
\end{tabular}

Berdasarkan hasil perhitungan korelasi rank spearman, maka hubungan nilai anak psikolgis dengan tingkat pendidikan anak keluarga petani di Kelompok Tani Giri Senang termasuk dalam kategori lemah dengan nilai koefesien korelasi 0,19 dan dengan nilai signifikansi sebesar 0,282 yang berarti hubungan tidak signifikan.

\subsection{Hubungan Nilai Anak Ekonomis dengan Tingkat Pendidikan Anak}

Hasil perhitungan korelasi rank spearman antara nilak anak ekonomis dengan tingkat pendidikan anak ditunjukkan dalam Tabel 10.

Tabel 10. Korelasi Nilai Anak Ekonomis dengan Tingkat Pendidikan Anak

\begin{tabular}{cccc}
\hline Karakteristik & Koefesien Korelasi & Signifikansi (2-tailed) & Keterangan \\
\hline Nilai Anak Ekonomis & 0,007 & 0,969 & Tidak Signifikan \\
\hline
\end{tabular}

Berdasarkan hasil perhitungan korelasi rank spearman, maka hubungan nilai anak psikolgis dengan tingkat pendidikan anak keluarga petani di Kelompok Tani Giri Senang termasuk dalam kategori lemah dengan nilai koefesien korelasi 0,07 dan dengan nilai signifikansi sebesar 0,969 yang berarti hubungan tidak signifikan.

\subsection{Hubungan Nilai Anak Sosial dengan Tingkat Pendidikan Anak}

Hasil perhitungan korelasi rank spearman antara nilak anak sosial dengan 
tingkat pendidikan anak ditunjukkan dalam tabel 11.

Tabel 11. Korelasi Nilai Anak Sosial dengan Tingkat Pendidikan Anak

\begin{tabular}{cccc}
\hline Karakteristik & Koefesien Korelasi & Signifikansi (2-tailed) & Keterangan \\
\hline Nilai Anak Sosial & 0,301 & 0,084 & Tidak Signifikan \\
\hline
\end{tabular}

Berdasarkan hasil perhitungan korelasi rank spearman, maka hubungan nilai anak psikolgis dengan tingkat pendidikan anak keluarga petani di Kelompok Tani Giri Senang termasuk dalam kategori lemah dengan nilai koefesien korelasi 0,301 dan dengan nilai signifikansi sebesar 0,085 yang berarti hubungan tidak signifikan.

\subsection{Hubungan Persepsi Keluarga tentang Pendidikan Anak dengan Tingkat Pendidikan Anak Keluarga Petani}

Hasil perhitungan korelasi rank spearman antara persepsi keluarga tentang pendidikan anak dengan tingkat pendidikan anak ditunjukkan dalam Tabel 12.

Tabel 12. Hubungan Persepsi Keluarga Petani tentang Pendidikan Anak dengan Tingkat Pendidikan Anak Keluarga Petani

\begin{tabular}{|c|c|c|c|c|}
\hline Karakteristik & & Koefesien Korelasi & Signifikansi (2-tailed) & Keterangan \\
\hline $\begin{array}{l}\text { Persepsi Keluarga } \\
\text { Pendidikan Anak }\end{array}$ & tentang & 0,166 & 0,347 & Tidak Signifikan \\
\hline
\end{tabular}

Berdasarkan hasil perhitungan korelasi rank spearman di atas, maka hubungan persepsi keluarga Petani tentang pendidikan anak dengan tingkat pendidikan anak keluarga petani di Kelompok Tani Giri Senang termasuk dalam kategori lemah dengan nilai koefesien korelasi 0.166 dan dengan nilai signifikansi sebesar 0,347 yang berarti hubungan tidak signifikan.

\subsection{Hubungan Nilai Anak dan Persepsi Keluarga tentang Pendidikan Anak dengan Tingkat Pendidikan Anak Keluarga Petani}

Dari hasil penelitian setelah dilakukan uji korelasi, hubungan antara nilai anak baik itu psikologis, ekonomis, dan sosial dengan tingkat pendidikan anak Keluarga Petani Kelompok Tani Giri Senang dan hubungan antara persepsi keluarga tentang pendidikan anak dengan tingkat pendidikan anak Keluarga Petani Kelompok Tani Giri Senang termasuk dalam kategori hubungan yang lemah dan tidak signifikan. Hal ini mengartikan bahwa variabel di atas memiliki hubungan namun sangat lemah dan tidak berarti. Berbeda dengan hasil penelitian Hastuti (2011) dan Nurkharomah et al (2015) yang menyatakan bahwa nilai anak 
memiliki hubungan dengan tingkat pendidikan anak dan tingkat pendidikan memiliki hubungan dengan persepsi orang tua.

Hal ini mengindentifikasikan bahwa terdapat faktor lain yang menentukan tingkat pendidikan anak. Dari hasil di lapangan adanya faktor biaya untuk menyekolahkan anak yang cukup besar dan ini menjadi faktor paling besar rendahnya tingkat pendidikan anak anggota Kelompok Tani Giri Senang dikarenakan pendapatan anggota tiap tahunnya yang rata-rata hanya cukup untuk biaya makan sehari-hari. Berkaitan dengan hasil nilai anak yang menunjukkan nilai anak ekonomis dalam kategori sedang dimana orang tua tidak terlalu menganggap anak sebagai investasi keluarga dan lebih memilih anak menentukan keputusannya sendiri untuk masa depannya dan tidak banyak berinvestasi di bidang pendidikan anak dapat menjadi salah satu faktor rendahnya tingkat pendidikan anak. Faktor lain karena kurangnya motivasi anak untuk bersekolah, meskipun persepsi keluarga tentang pendidikan anak sangat tinggi tetapi dapat berbeda dengan persepsi anak tentang pendidikan. Karena faktor lingkungan sosial anak lebih memilih untuk bekerja dan menghasilan uang sendiri dibandingkan melanjutkan pendidikan.

\section{KESIMPULAN DAN SARAN}

Berdasarkan hasil analisis pada penelitian ini disimpulkan:

1. Sebagian orangtua setuju bahwa anak lebih memiliki nilai secara psikologis dibandingakan dengan nilai anak secara sosial dan ekonomis.

2. Persepsi keluarga petani tentang pendidikan anak termasuk dalam kategori sangat baik. Seluruh responden yang setuju bahwa pendidikan sangat penting bagi anak.

3. Tingkat pendidikan anak keluarga petani di Kelompok Tani Giri Senang didominasi tingkat pendidikan Sekolah Dasar (SD), kedua tingkat SMA, ketiga tingkat SMP, keempat adalah belum bersekolah, dan dengan dengan presentase terendah berada pada tingkat perguruan tinggi.

4. Dalam hubungan nilai anak dan persepsi keluarga tentang pendidikan anak dengan tingkat pendidikan anak keluarga petani Kelompok Tani Giri Senang memiliki korelasi yang sangat lemah dan tidak signifikan.

Berdasarkan hasil analisis peneliti menyarankan beberapa hal sebagai berikut: 
1. Kelompok Tani Giri Senang lebih sering untuk mengajak masyarakat Desa Giri Mekar usia muda khususnya yang tidak melanjutkan pendidikan untuk bergabung dalam manajemen produksi Kopi Palasari agar tetap memiliki kegiatan yang produktif.

2. Kelompok Tani Giri Senang untuk lebih banyak mengikutsertakan anggotanya untuk masuk kedalam manajemen pengolahan dan produksi kopi palasari sehingga dapat meningkatkan pendapatan per tahun anggota.

3. Orang tua secara aktiv memotivasi anaknya untuk terus melanjutkan pendidikan dan memberikan wawasan kepada anak pentingnya pendidikan bagi kehidupan.

4. Dengan didapatkan faktor lain yang menyebabkan rendahnya tingkat pendidikan anak, diharapkan adanya penelitian lain yang menganalisis faktor lain penyebab rendahnya tingkat pendidikan anak di Kelompok Tani Giri Senang sehingga dapat melengkapi skripsi ini.

\section{DAFTAR PUSTAKA}

Astuti, Sidharta A., Ellyn N. 2017. Pemetaan Tingkat Kesejahteraan Keluarga di Kecamatan
Banjarmasin Selatan. Jurnal Pendidikan Geografi, Vol. 4, No. 2, Hal 20-34

Badan Pusat Statistik Jawa Barat. 2020. Angka Partisipasi Sekolah per Kota/Kabupaten di Jawa Barat Tahun 2017-2019. Jawa Barat : Badan Pusat Statistik

Badan Pusat Statistik Jawa Barat. 2020. Jumlah Presentase Penduduk Miskin di Jawa Barat 2018-2020. Jawa Barat : Badan Pusat Statistik

Bahri N. M. 2013. Pengaruh Nilai Anak terhadap Perilaku Investasi Anak pada Keluarga Miskin dan Tidak Miskin. Skripsi. Fakultas Ekologi Manusia Institut Pertanian Bogor.

Basrowi, Siti J. 2010. Analisis Sosial Ekonomi dan Tingkat Pendidikan Masyarakat Desa Srigading, Kecamatan Labuhan Maringgai, Kabupaten Lampung Timur. Jurnal Ekonomi Pendidikan, Vol. 7 No. 2. Hal. 58-81

Fahmi S., M. Pinem. 2018. Analisis Nilai Anak dalam Gerakan Keluarga Berencana bagi Keluarga Melayu. Jurnal Pendidikan Ilmu-Ilmu Sosial, Vol. 10 No. 1, Hal. 112-119

Hartoyo, M. Latifah, S. R. Mulyani. 2011. Studi Nilai Anak, Jumlah Anak yang diinginkan, dan Keikutsertaan Orang Tua dalam Program KB. Jur. Ilm. Kel. \& Kons., Vol. 4 No. 1, Hal 37-45

Hariyati W. 2015. Makna Pendidikan Anak bagi Keluarga Petani Sawit di Desa Rambah Jaya Kecamatan Bangun Purba Kabupaten Rokan Hulu. Jom Fisip, Vol. 2 No. 2

Hastuti R. 2011. Analisis Nilai Anak, Kualitas Pengasuhan, dan Perkembangan Anak Usia Prasekolah pada Keluarga Petani Karet dan Kelapa Sawit di Kabupaten Bungo. Skripsi. Fakultas Ekologi Manusia Institut Pertanian Bogor 
Hoffman L. W., A. Thornton, J. D. Manis. 1978. The Value of Children to Parents in The United States. Journal of Population, Vol. 1 No. 2

Istiqomah Eni.2014. Nilai Anak pada Keluarga Petani Kelapa Sawit. Jom FISIP, Vol. 1 No. 2. Hal 1-15

Kagitchibasi, C. 2004. The Value of Children : A Key to Gender Issues. From:

www.healthnet.org.np/pediatric/kag .html.

Kasnodihardjo. 2014. Nilai Anak dalam Keluarga dan Upaya Pemeliharaan Kesehatannya (Suatu Study Etnografi di Desa Gadingsari, Kabupaten Bantul. Jurnal Ekologi Kesehatan, Vol. 13, No. 4, Hal 354362.

Kohlmann, Annette. 2002. Fertility Intentions in a Cross-Cultural View: The Value of Children Reconsidered.

Mustamin S. H. 2013. Faktor-Faktor Pengaruh Tingkat Pendidikan Anak di Pemukiman Kumuh Kota Makassar. Lentera Pendidikan, Vol. 12 No. 2. Hal 151-165

Nurkholis. 2013. Pendidikan dalam Upaya Memajukan Teknologi. Jurnal Kependidikan, Vol. I, No. 1, Hal 25

Prasanti D.P. 2013. Nilai Anak pada Ibu dengan Status Sosial Ekonomi Tinggi Ditinjau dari Etnis Jawa. Jurnal Ilmiah Mahasiswa Universitas Surabaya, Vol. 2 No.3. Hal 1-14

Pratiwi D. S., Ajeng A.W., Mria M. R. 2018. Persepsi Orang Tua terhadap Pendidikan Anak Usia Dini di Lingkungan RW 01 Dukuh Krajan Kota Salatiga. Satya Widya, Vol. 34 No. 1, Hal 39-49

Pratiwi N. K. 2015. Pengaruh Tingkat Pendidikan, Perhatian Orang Tua, dan Minat Belajar Siswa terhadap
Prestasi Belajar Bahasa Indonesia Siswa SMK Kesehatan di Kota Tangerang. Jurnal Pujangga, Vol. 1 No.2, Hal. 75-105

Pusat Data dan Statistik Pendidikan dan Kebudayaan. 2020. Jumlah Siswa Putus Sekolah Menurut Tingkat Tiap Propinsi. Jakarta Pusat : Pusat Data dan Statistik Pendidikan dan Kebudayaan

Rofi Sofyan. 2018. Pandangan Keluarga Petani terhadap Pendidikam Anak. TARLIM, Vol. 1 No. 1

Sardi, J,.Hasbiullah. 2016. Pengaruh Pendapatan Petani Terhadap Tingkat Pendidikan Anak di Kecamatan Lamasi Timur Kabupaten Luwu. Vol. 3, No. 1, Hal 58-70

Sari S. M. Refti H. L. 2017. Persepsi Nilai Anak Dalam Pengaturan Kelahiran pada Pasangan Usia Subur. Paradigma, Vol 05 No. 1. Hal. 1-7

Simpsons, J. 1999. The Envolving Value of Children.

Siregar. Nina. S.S. 2013. Persepsi Orang Tua terhadap Pentingnya Pendidikan bagi Anak. Jurnal Ilmu Pemerintahan dan Sosial Politik, Vol. 1 No.1, Hal. 11-27

Siswanto. Agus. 2017. Pelaksanaan Program Rintisan Wajib Belajar 12 Tahun Pada Sekolah Menengah Atas di Kabupaten Bantul. Jurnal Hanata Widya Vol. 6 No. 7, Hal 55-65

Susanti D., N. H. Listiana, T. Widayat. 2016. Pengaruh Umur Petani, Tingkat Pendidikan, dan Luas Lahan terhadap Hasil Produksi Tanaman Sembung. Vol. 9 No.2, Hal. 75-82

Solina. Wira. 2017. Persepsi Orang Tua tentang Pendidikan. Konselor, Vol. 6 No.3, Hal. 91-95

Tapondhadhai A. T., Ansofino, Ranti N. 2012. Persepsi Masyarakat Petani 
Kelapa terhadap Pendidikan Tinggi Anak di Kecamatan Siberut Barat, Kabupaten Kepulauan Mentawai. Jurnal Ilmu Sosial Mamangan, Vol. 1 No. 2. Hal 102-108

Trommsdorff G., B. Nauck. 2005. The value of children in cross-cultural perspective. Case studies in eight societies.

Waki A. 2017. Persepsi Orang Tua terhadap Pendidikan INKLUSIF
Sekolah Dasar di Kecamatan Gunung Putri Kabupaten Bogor Provinsi Jawa Barat. Jurnal Basicedu, Vol.1 No. 1. Hal. 79-83

Zulfitri. N. M. 2013. Studi Deskriptif : Nilai Anak Bagi Orang Tua yang Memiliki Anak Tunggal. Jurnal Ilmiah Mahasiswa Universitas Surabaya, Vol. 2 No. 2, Hal. 1-11 